\title{
Utilization of Geodiversity Potential for Purification of Drinking Water as Local Wisdom
}

\author{
$1^{\text {st }}$ Nurul Hikmah Kartini \\ Elementary School Teacher Education \\ Study Program, Universitas \\ Muhamadiyah Palangkaraya \\ Palangka Raya, Central Kalimantan, \\ Indonesia \\ nurulkartini77@gmail.com
}

\author{
$2^{\text {nd }}$ Ayu Krishna Yuliawati \\ Management Study Program, \\ Universitas Pendidikan Indonesia \\ Bandung, West Java, Indonesia
}

\author{
$3^{\text {rd }}$ Mohamad Sapari Dwi Hadian \\ Sustainable Tourism Study Program \\ Universitas Padjadjaran \\ Bandung, West Java, Indonesia
}

\begin{abstract}
South Kalimantan has productive geodiversity potential. The distribution of limestone is spread across several districts, including Tabalong, Rantau, and Kotabaru. Utilization of this rock has been carried out by the Banjar tribe along the river since ancient times as a filter for river water for drinking water needs. This study aims to obtain a clear picture of the benefits of geodiversity in the form of limestone for water filters. The method used in the form of laboratory tests on limestone and limestone filter water. To ensure that the material used for water filters is used, a thin incision (thin-section) to determine the type of rock and calculate the permeability and porosity of the rocks used. The results of the study found that the stone increases the $\mathrm{pH}$ value and neutralizes the water along with the enrichment of the major elements of filtered river water. The use of local limestone for water filters is still used by the Banjar tribe community along the river of the Hulu Sungai Utara River in South Kalimantan as a pearl of local wisdom that needs to be preserved and can be judged as a unique local technology, environmentally friendly and by a sustainable environment.
\end{abstract} Water

Keywords-Utilization, Geodiversity, Purification, Drinking

\section{INTRODUCTION}

Karst area is a unique area that develops on limestone because the dissolution process, besides being used as a residence, also has the function of storing water, science, and geotourism. Therefore, anticipatory steps need to be taken, but on the other hand, limestone has a high potential sale value because as the primary raw material for cement, paint, medicines, cosmetics, toothpaste, and other industries being used by the local community as building materials. Incorrect use of karst limestone will harm the karst environment, such as loss of natural karst landscape, damage to caves that have stalagmites, stalactites, rock grooves, loss of cultural and biological value, loss of groundwater quality and pollution from groundwater, etc. Development of an area is an activity to increase the intensity of interaction between the elements forming an area and will change the function of land that must be adjusted to the carrying capacity of land and natural resources so that the development carried out does not exceed the carrying capacity and does not cause environmental damage.

Haryono (2000), argues that the results of the investigation obtained the characteristics of a karst area, which includes karstification and forms produced, water behavior (hydrology and hydrogeology), stability and carrying capacity. Information about the level of karstification in an area can be used as primary data and consideration for the direction of regional development (urban). The karstification level consists of holokarst zakat (karst is well developed, almost all karst characteristics can be found), so it is a protected area of function, mesokarst zakat (karst is not well developed, karst appearance is rarely found), so it is a buffer zone (so the area is buffered buffer function) activities that can change the landscape with stringent requirements), and non-karst zakat (carbonate rocks do not have karst characteristics), so it is an area that has a cultivation function.

The study was conducted in an area along the river of the country, South Kalimantan. This area is included in vast plains and full rivers, geographically showing abundant water potential, on the other hand, its $\mathrm{pH}$ value is $4.5-5.5$ with BOD water quality 4.5-5.5 mg/L; COD 12.0 - 22.4 $\mathrm{mg} / \mathrm{L}$; DO $4.1-5.2 \mathrm{mg} / \mathrm{L}$. This area is a swamp that has a reasonably low acidity value. To anticipate the value of local water acidity, the wisdom of the Banjar people around the river uses natural filters using local rocks around the hill.

\section{METHOD}

The method used in this study is qualitative and quantitative. Qualitative using observations and secondary data, by studying reports and papers from previous studies, and interpreting topographic maps (Rupa Bumi Indonesia/RBI maps) scale of $1: 50,000$, studying 
Geological Maps of Banjarmasin and Amuntai Sheets, Kalimantan, scale of 1 : 250,000 (Heryanto, R., Sanyoto, P., Supriatna, S., et al., 1981), and the Geology of the Barito Basin, Kalimantan (Heryanto, R., 2010).

The interpretation of the map is made to find out the origin of rocks. From geographic imagery data, geomorphic aspects of information are obtained, and to describe the condition of the landscape and natural formations of each unit, soil/rock forming it, and the processes/geological phenomena that influence it. Porosity calculations are also carried out at this stage. Slices of rock were also carried out by the research team. In the saturation (or imbibition) method, clean and dry rocks are weighed before full saturation with wetting liquid (Wdry.

\section{RESULTS AND DISCUSSION}

\section{A. Carbonate Rock Formation}

Based on the Geological Map of the Banjarmasin and Amuntai Sheets, Kalimantan, scale of 1: 250,000 (Heryanto, R., Sanyoto, P., Supriatna, S., et al.,1981), karstic limestone in the study area and its surroundings is limestone originating from the Formation Berai (Tomb) The Berai (Tomb) Formation, dominated by gray-white limestone, partially layered well enough to show thickening upward, that is, $20 \mathrm{~cm}$ to $200 \mathrm{~cm}$ thick, this rock is also rich in coral, foraminifera, and algae, intertwined. Marlum is light gray, solid, well-coated, 10$15 \mathrm{~cm}$ thick, contains plankton foraminifera, and claystone is gray, locally flaked, $25-75 \mathrm{~cm}$ thick.

B. Use of Limestone Filters in the Community of South

\section{Kalimantan}

The stages of the process of processing water from river water into clean water consist of several stages, namely Entering water into a basin (container) of water made of limestone $(\mathrm{CaCO} 3)$ in the hope of water neutralization from acidic $\mathrm{pH}$ to approaching neutral $\mathrm{pH}$, the droplets from the container react with air (Aeration), and coagulation/sediment will be at the bottom of the container so that filtering will continue to occur with the gravity system. The chart of the water filtration process is presented in Figure 1.

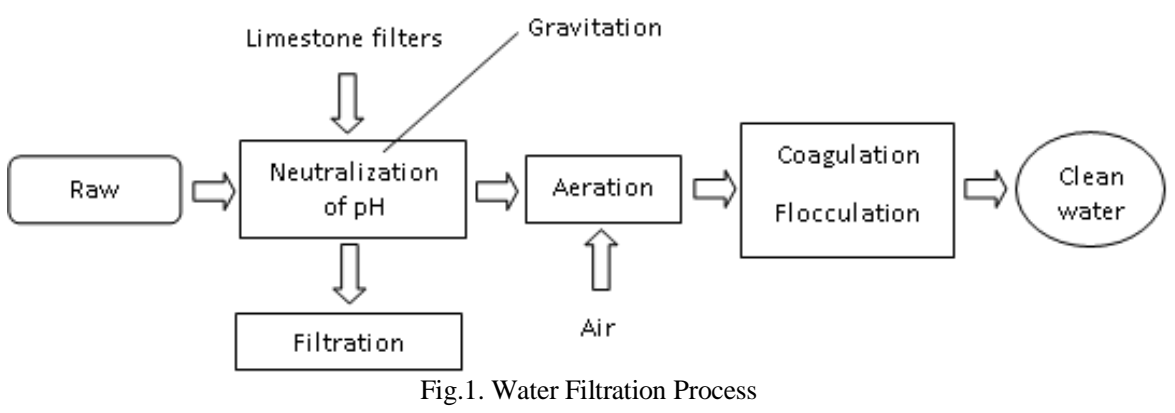

Stone slices originating from the filter stones above are in the Banjar tribal community along the riverbanks of the Nagara river. The sieve above is based on the local wisdom of the Banjar tribe. The filtering process is that river water is deposited one night then put into a filter stone. From three informants, two of them said that they directly consumed drinking water that trickled out of the filter stone, which was accommodated in a jug/tajau. There is only one person who uses a different method that is by boiling it first. The appearance of the tajau stone filter itself is presented in Figure 2. Based on interviews, during decades of living by consuming water directly, two informants stated that they had never been stricken with a disease related to water consumption.

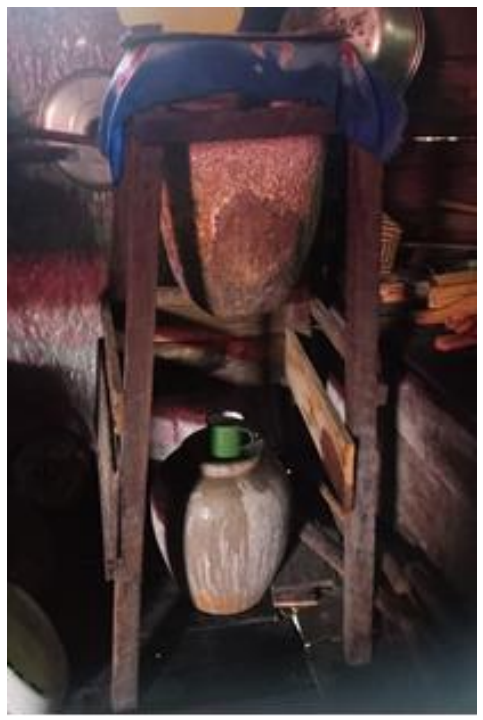

Fig. 2. Tajau stone filter 


\section{Photographs and Microscopic Descriptions}

Figure 3 shows the incision results from the tajau filter stone. Based on the description of Megaskops included in clastic limestone characterized by carbonated material, benthonic foraminifera fossils, planktonic, dirty white, fine-grained - medium, open packaging, sub-angular grain form. This incision is brownish-white (PPL), dark brown (XPL). The depositional texture is visible, and the components are not bound. It contains mud supported (Grain 35\% and mud $65 \%$ ), has $>10 \%$ grains. Grains consist of skeletal components $(15 \%)$, non- skeletal $(10 \%)$, minerals $(15 \%)$, Mud micrite (50\%), and sparits (10\%).

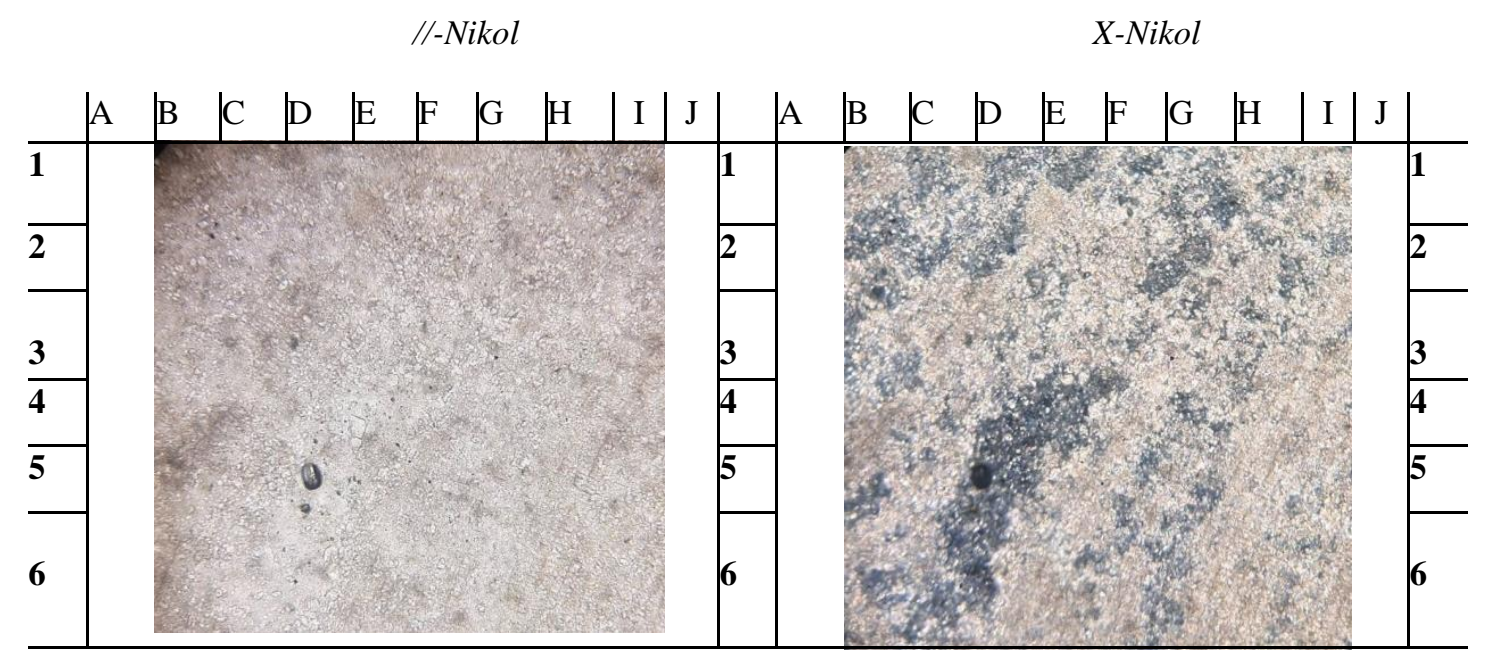

Fig. 3. Incision results from the tajau filter stone (50 times magnification)

Grain:

1. Fossil/Skeletal Grain (15\%): Light brown (PPL) dark brown (XPL), absent pleochroism, low relief, in the form of benthonic foraminifera fossils, and planktonic spreading in various places on rocks.

2. Non-Skeletal Fossils (10\%): Grain in this rock is in the form

3. Ooid (5\%)

4. Pelloid $(2 \%)$

5. Oncoid (3\%)

6. Minerals (15\%):

7. Mineral Carbonate (15\%): Colorless (PPL) Light brown (XPL), mineral> medium, high-medium relief, low pleochroism, subangular mineral form, no hemisphere, no twins, no order interference color I. Mud:

1. Micritic (50\%): Gray (PPL), blackish gray (XPL), high interference color.

2. Sparit (10\%): Colorless (PPL), gray (XPL), high interference color.
Porosity and Permeability All rocks contain pore space. Porosity is the percentage of the volume of most of the stones occupied by pores. Vacancies in bedrock are openings where groundwater can be stored. Where voids are connected, they also provide a pathway for groundwater to flow. Permeability is a measure of how much soil flows or migrates through an aquifer. A stone may be porous, but unless the pores are connected, the permeability will be low. In general, the permeability of rocks in well-developed karst regions is very high when broken tissue has been enlarged and connected with a solution. In most limestone, primary porosity and permeability, or hydrological characteristics made like formed rocks, are generally low. However, in karst regions, large caves of porosity and high permeability are common. These hydrological characteristics include fractures and openings enlarged with solutions, almost always secondary or tertiary features that are created or improved after the rock is formed. 


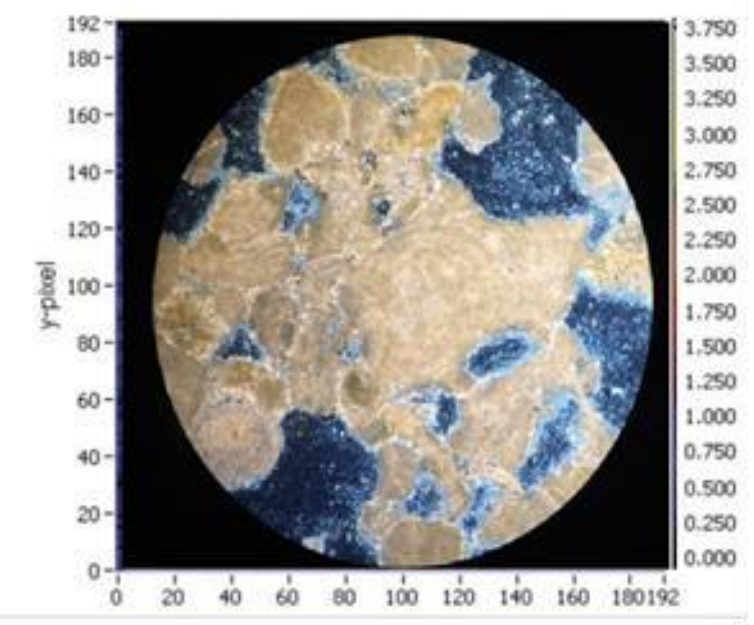

Fig. 4. Thin section, petrographic analysis

The development of settlements in many carbonate rocky areas in Indonesia should receive even greater attention because based on the diversity of characteristics and potential resources in the rocky carbonate area in Indonesia, it requires unique and different efforts in its development. It must primarily consider karstification symptoms that exist in the region (Haryono, 2000).

\section{CONCLUSION}

The local wisdom of the Banjar tribe in consuming drinking water through the stone filter "tajau" still exists and is still maintained. Based on the results of the analysis of the rock incision from the stone filter shows that the initial suspicion of this stone filter is a type of limestone. Also found fossils are from marine sediments or shallow marine depositional environments. The implication of the results of this study on the development of geoproducts is as information material for further research. After the rock incision analysis test is carried out, further research will attempt to find the origin of the rock and estimate the technical, strategic testing of making a similar product, in this case, rock water filters.

\section{REFERENCES}

[1] Bisri, D., 2013 : Penyelidikan Geologi Lingkungan Kawasan Karst Kabupaten Tapin, Provinsi Kalimantan Selatan, Pusat Sumber Daya Air Tanah Dan Geologi Lingkungan, Bandung

[2] Firmansyah, Y., Restu, A., Suganda, B. R., Hadian, M. S. D., \& Gani, R. M. G. (2018). Potency Of Soil Water In Masinam Island Based On The Rock Resistivity Value. Journal Of Geological Sciences And Applied Geology, 2(5).

[3] Haryono, E., 2000 : Sumber Daya Alam Di Kawasan Pesisir Dan Pulau-Pulau Kecil Berbatuan Karbonat. Prosiding Seminar Nasional Pengelolaan Ekosistem Pantai Dan Pulau-Pulau Kecil Dalam Konteks Negara Kepulauan, Fakultas Geografi Ugm, Yogyakarta, H. $176-186$.

[4] Heryanto, R., Sanyoto, P., Dan Supriatna, S., 1981 : Peta Geologi Lembar Banjarmasin Dan Amuntai, Kalimantan, Skala 1 : 250.000, Pusat Penelitian Dan Pengembangan Geologi, Bandung

[5] Heryanto, R., 2010 : Geologi Cekungan Barito, Kalimantan, Badan Geologi

[6] Hadian, M. S. D., Yuliwati, A. K., \& Pribadi, K. N. (2016). Increasing Community Environmental Awareness Through Geodiversity Conservation Activities At Ciletuh, Sukabumi, West Java. Journal Of Environmental Management \& Tourism, 7(2), 14

[7] Hadian, M. S. D., Waliana, T. Y., Sulaksana, N., Putra, D. B. E., \& Yuskar, Y. (2017). Hydrochemistry And Characteristics Of
Groundwater: Case Study Water Contamination At Citarum River Upstream. Journal Of Geoscience, Engineering, Environment, And Technology, 2(4), 268-271.

[8] Lamoreaux, Philip E., 1993, Living With Karst. Agi Environmental Awarenees Series 4, American Geological Institute In Cooperation With National Speleological Society, Usa, $64 \mathrm{H}$.

[9] Samodra, H., 2001, Nilai Strategis Kawasan Kars Di Indonesia Pengelolaan Dan Perlindungannya. Publikasi Khusus, Pusat Penelitian Dan Pengembangan Geologi, Bandung, $318 \mathrm{H}$. 